\title{
PEMERIKSAAN KIMIA DARAH (GLUKOSA DARAH, KOLESTEROL DAN ASAM URAT) MENGGUNAKAN METODE STICK TEST DAN METODE SPEKTROFOTOMETRI DARI SAMPEL DARAH MASYARAKAT RW 22 KELURAHAN NUSUKAN KECAMATAN BANJARSARI KOTA SURAKARTA
}

\author{
Rinda Binugraheni'), Susan Primadevi ${ }^{2)}$, Rahmat Budi Nugroho ${ }^{3)}$, Dian Kresnadipayana ${ }^{4)}$, \\ Gregorius Indra Budianto ${ }^{5}$ \\ 1), 2), 3),4) Fakultas IImu Kesehatan Universitas Setia Budi Surakarta \\ Email: rinda.binugraheni@gmail.com \\ 5) Fakultas Tehnik Kimia Universitas Setia Budi Surakarta
}

\begin{abstract}
Nusukan is one village with a tendency for people who prefer to consume fast food and lack of attention to a healthy lifestyle. This causes a lot of society are affected by diabetes mellitus, hyperlipidemia and uric acid. Nusukan society RW 22 who are not aware that they have the disease. For it is necessary to check blood glucose levels, cholesterol and uric acid that can be detected early. The purpose of this program is to provide education on the dangers and prevention of diabetes mellitus, hyperlipidemia, and uric acid. It is also to help people to detect diabetes mellitus, hyperlipidemia and uric acid using stick test and spektropothometry method. Of the 30 people there were seven people who are abnormal blood glucose levels or diabetes mellitus, according stated test stick method, whereas in spectrophotometric methods there are 2 people. Uric acid test of RW 22, there are 7 people who exceed the normal limits, whereas cholesterol levels there are 22 people who exceed normal cholesterol levels (hyperlipidemia) with a test stick method, whereas in sprektropothometry there are 18 people who hyperlipidemia. Methods stick test results show higher levels compared to the spectrophotometric method.
\end{abstract}

Keywords: Blood chemistry, Stick test, spectrophotometry

\section{PENDAHULUAN}

Sekarang ini masyarakat memiliki kecenderungan tinggi untuk mengkonsumsi makanan yang praktis dan cepat saji (fast food). Jenis makanan ini sangat digemari karena kepraktisannya mengingat tingkat kesibukan masyarakat yang selalu meningkat dari tahun ke tahun. $\mathrm{Hal}$ ini dapat berakibat buruk bagi kesehatan, ditambah lagi kebiasaan masyarakat yang jarang berolahraga dan tidak menerapkan pola hidup sehat. Perubahan pola kehidupan yang seperti ini, dapat memicu berbagai penyakit degeneratif, antara lain jantung koroner dan stroke. Penyakit jantung koroner dan stroke dapat disebabkan oleh beberapa faktor antara lain kadar glukosa darah, kolesterol dan asam urat yang tinggi. Penyakit jantung koroner menjadi penyebab kematian bagi 35 persen warga Indonesia dan di wilayah Asia sudah terjadi 1,8 juta kasus selama tahun 2014.

Kelurahan Nusukan, merupakan salah satu kelurahan yang memiliki masyarakat dengan kecenderungan lebih suka mengkonsumsi makanan cepat saji dan kurang perhatian terhadap pola hidup sehat terutama masyarakat di RW 22 Nusukan. Masyarakat disana memiliki kebiasaan jarang berolahraga, suka merokok dan lebih suka mengkonsumsi makanan cepat saji. Kebiasaan tersebut dimungkin terjadi karena tingkat kesibukan masyarakat yang semakin tinggi dan 
kurangnya perhatian terhadap kesehatan. $\mathrm{Hal}$ ini menyebabkan banyak masyakarat Nusukan RW 22 yang terjangkit penyakit diabetes melitus, hiperlipidemia, dan asam urat, dan terkadang mereka tidak menyadari bahwa mereka mengidap penyakit tersebut. Untuk itu perlu diadakan pemeriksaan kadar glukosa darah, kolesterol dan asam urat sehingga bisa terdeteksi sejak dini serta diadakan penyuluhan tentang pentingnya pola hidup sehat dan pencegahan penyakit diabetes melitus, hiperlipidemia serta asam urat.

Masyarakat yang tinggal di RW 22

Kelurahan Mojosongo mempunyai kebiasaan pola hidup yang tidak sehat sehingga rawan sekali terjangkit penyakit degeneratif antara lain jantung koroner. Pengelolaan kadar glukosa darah, kolesterol dan asam urat serta pengetahuan tentangnya menjadi penting dalam upaya pencegahan dan penurunan resiko untuk terkena penyakit jantung koroner dan peningkatan kualitas hidup masyarakat. Tujuan mengadakan pemeriksaan kadar glukosa darah, kolesterol dan asam urat serta memberikan penyuluhan tentang pola hidup adalah memberikan penyuluhan tentang pencegahan penyakit diabetes melitus, hiperlipidemia dan asam urat, membantu masyarakat untuk mendeteksi penyakit diabetes melitus, hiperlipidemia dan asam urat dengan melalukan pemeriksaan kadar glukosa darah, kolesterol dan asam urat menggunakan metode Stick Test dan metode Spektrofotometri.

\section{METODE}

Untuk mengatasi salah satu permsalahan yang ada di Kelurahan Nusukan RW 22 yaitu mengenai kebiasaan pola hidup tidak sehat dan rawan terserang penyakit degeneratif maka salah satu upaya yang dapat dilakukan yaitu dengan mengadakan pemeriksaan kesehatan dengan melakukan pemeriksaan kimia darah (Glukosa darah, asam urat, kolesterol) serta memberikan penyuluhan tentang pola hidup sehat serta bahaya dan cara pencegahan penyakit degenerative tersebut. Metode pelaksanaan progam pengabdian ini adalah Mengurus perijinan kepada kepala desa dan ketua RW 22, Pemeriksaan kadar glukosa darah, kolesterol dan asam urat menggunakan metode Stick Test, Pengujian kadar glukosa darah, kolesterol dan asam urat dengan menggunakan metode spektrofotometri, Penyuluhan dan pembagian hasil pemeriksaan kadar glukosa darah, kolesterol dan asam urat.

\section{HASIL DAN PEMBAHASAN}

Kegiatan pengabdian ini dilakukan di kelurahan Nusukan, RW 22 Kecamatan Banjarsari, Kota Surakarta.Kegiatan ini dilakukan dalam dua kali pertemuan yaitu pada tanggal 5 Februari 2016 dan 12 Februari 2016.

Kegiatan pengabdian ini mengundang 30 warga RW 22 kelurahan Nusukan.Mayoritas warga yang datang adalah para lansia. Hal ini kemungkinan dikarenakan para lansia merasa sangat penting sekali untuk memeriksa kadar glukosa, kolesterol atau asam urat.

\section{Pemeriksaan glukosa darah, kolesterol dan asam urat menggunakan metode stick test dan spektrofotometri}

Salah satu tujuan pemeriksaan ini adalah untuk membantu masyarakat mendeteksi lebih dini penyakit degeneratif, sehingga dapat menindaklanjuti secara cepat. Dari 30 warga yang diperiksa kadar glukosa darah, kolesterol dan asam urat, menunjukan hasil bahwa terdapat 7 warga yang kadar glukosa darahnya melebihi normal atau dinyatakan diabetes melitus menurut metode stick test, sedangkan secara metode spektrofotometri terdapat 2 warga saja. Hasil uji asam urat warga RW 22, secara umum normal, sedangkan kadar kolesterol terdapat 22 warga yang kadar kolesterolnya melebihi normal (hiperlipidemia) dengan metode stick test, sedangkan secara sprektrofotometri terdapat 18 warga. 
Tabel 1. Hasil pemeriksaan kadar glukosa, kolesterol dan asam urat warga RW 22

\begin{tabular}{|l|l|l|c|c|c|c|}
\hline \multirow{2}{*}{ Metode } & \multicolumn{2}{|c|}{ Kadar glukosa } & \multicolumn{2}{c|}{ Kadar asam urat } & \multicolumn{2}{c|}{ Kadar kolesterol } \\
\cline { 2 - 7 } & Normal & $\begin{array}{c}\text { Diabetes } \\
\text { melitus }\end{array}$ & Normal & Asam urat & Normal & hiperlipidemia \\
\hline Stick test & 23 warga & 7 warga & 23 warga & 7 warga & 8 warga & 22 warga \\
\hline Spektrofotometri & 28 warga & 2 warga & - & - & 12 warga & 18 warga \\
\hline
\end{tabular}

Dari Tabel 1. menunjukan bahwa adanya perbedaan hasil pemeriksaan menggunakan metode stick test dan spektrofotometri. Metode stick test cenderung menunjukan hasil yang lebih tinggi kadarnya, dibandingkan dengan metode spektrofotometri, sehingga menghasilkan lebih banyak warga yang kadarnya melebihi nilai normal. Untuk menegakkan diognosa klinis, dianjurkan memakai metode spektrofotometri, sedangkan metode stick test hanya untuk pemantauan kadar saja.

Menurut Syabatini (2010), spektofotometri merupakan suatu metode analisa yang didasarkan pada pengukuran serapan sinar monokromatis oleh suatu lajur larutan berwarna pada panjang gelombang spesifik dengan menggunakan monokromator prisma atau kisi difraksi dengan detektor fototube. Spektofotometri dapat dianggap sebagai perluasan suatu pemeriksaan visual dengan studi yang lebih mendalam dari absorbsi energi.

Metode spektrofotometri memiliki kelebihan, yaitu : presisi tinggi, akurasi tinggi, spesifik, relatif bebas dari gangguan (kadar hematokrit, vitamin C, lipid, volume sampel, dan suhu). Sedangkan kekurangannya adalah memiliki ketergantungan pada reagen, butuh sampel darah yang banyak, pemeliharaan alat dan reagen memerlukan tempat yang khusus dan membutuhkan biaya yang cukup mahal. Sedangkan metode stick test akurasinya belum diketahui, dan memiliki keterbatasan yang dipengaruhi oleh kadar hematokrit, interfensi zat lain (Vitamin C, lipid, bilirubin dan hemoglobin), suhu, volume sampel yang kurang. Namun metode stick test juga memiliki kelebihan yaitu hasil pemeriksaan dapat segera diketahui, hanya butuh sampel sedikit, tidak membutuhkan reagen khusus, praktis dan mudah dipergunakan jadi dapat dilakukan oleh siapa saja tanpa butuh keahlian khusus
Hasil pemeriksaan baik menggunakan metode stick test maupun sprektrofotometri menunjukan bahwa penyakit yang paling banyak diderita warga RW 22 kelurahan Nusukan adalah hiperlipidemia, daripada 2 penyakit yang lainnya. Hiperlipidemia adalah suatu keadaan terjadinya peningkatan kolesterol dan atau trigliserida serum di atas batas normal. Hiperlipidemia sendiri merupakan salah satu faktor resiko dari Penyakit Jantung Koroner (Price Sylvia A., et al., 2006). Kemungkinan penyebab penyakit hiperlipidemia yang diderita warga RW 22 adalah faktor usia dan adanya perubahan pola makan yang cenderung ke makanan cepat saji serta penurunan aktifitas fisik pada masyarakat yang dapat mengakibatkan terjadinya ketidakseimbangan energi.

\section{Penyuluhan penyakit diabetes miletus, kolesterol, dan asam urat}

Penyuluhan tentang penyakit diabetes melitus, kolesterol dan asam urat dilakukan setelah pemeriksaan selesai. Penyuluhan ini bertujuan untuk memberikan informasi dan menjawab pertanyaan masyarakat mengenai penyakit diabetes melitus, asam urat dan hiperlipidemia.Penyuluhan dilakukan satu minggu setelah pemeriksaan. Selain penyuluhan juga ada pembagian hasil pemeriksaan baik menggunakan metode stick tes maupun spektrofotometri, sehingga warga yang hasil tes nya ada kadar yang tidak normal bisa bertanya langsung ke narasumbernya.

Penyuluhan yang dilakukan oleh tim abdimas ini mendatangkan narasumber yang sudah ahli dibidang kesehatan yaitu dr. Ratna Herawati. Penyuluhan berlangsung sekitar 2 jam. Warga RW 22 sangat antusias sekali mendengarkan penjelasan yang diberikan oleh dr. Ratna Herawati. Mereka juga menanyakan keluhan-keluhan yang sering dirasakan 
serta bagaimana cara pencegahan maupun pengobatan penyakit diabetes melitus, asam urat dan kolesterol.

Diskusi yang berlangsung hampir 2 jam, yang diselingi dengan tanya jawab masih dirasa kurang oleh warga RW 22 karena terlalu banyaknya warga yang ingin bertanya seputar penyakit yang dideritanya. Namun dengan adanya penyuluhan ini meraka dirasa sangat bermanfaat karena pengetahuan mereka bisa bertambah dan lebih sadar akan pentingnya menjaga kesehatan.

\section{KESIMPULAN DAN SARAN}

\section{A. Kesimpulan}

Kesimpulan dari kegiatan pengabdian ini adalah:

1. Pravelensi paling tinggi penyakit yang diderita warga RW 22 Kelurahan Nusukan adalah hiperlipidemia, dari pada diabetes melitus dan asam urat.

2. Terdapat perbedaan hasil tes, antara metode stick test dan spektrofotometri.

3. Metode stick test menunjukan hasil yang lebih tinggi kadarnya dibandingkan dengan metode spektrofotometri.

4. Pemahaman warga tentang penyakit diabetes melitus, asam urat dan kolesterol telah meningkat.

\section{B. Saran}

Saran yang dapat disampaikan adalah:

1. Pemeriksaan kadar glukosa, asam urat dan kolesterol belum menjangkau semua warga sehingga perlu dilakukan lagi secara lebih luas

2. Kegiatan ini perlu dilanjutkan lagi dengan kegiatan rutin bagi penderita hiperlipidemia, maupun diabetes melitus yang beresiko tinggi mengalami penyakit kardiovaskuler, untuk mencegah terjadinya penyakit tersebut.

3. Penyuluhan mengenai penyakit degeneratif perlu dilakukan lebih luas dan lebih lama sehingga pemahaman masyarakat lebih banyak lagi.

\section{UCAPAN TERIMA KASIH}

Ucapan terimakasih disampaikan kepada Lembaga Penelitian dan Pengabdian Kepada Masyarakat yang telah memberikan kesempatan dan mendanai kegaitan pengabdian yang telah dilakukan sehingga pelaksanaan kegiatan tersebut berjalan dengan lancar.

\section{DAFTAR PUSTAKA}

Price Sylvia A, Lorraine M. Wilson.2006. Patofisiologi Konsep Klinis ProsesProses Penyakit, edisi 6. Jakarta : Penerbit Buku Kedokteran EGC.

Syabatini, Annisa. 2010. Analisa Campuran Dua komponen Tanpa Pemisahan dengan Spektofotometer.Pontianak : UNLAM Press 